\title{
Scratching the Surface of Werner Syndrome and Human Ageing
}

Ageing is a universal, intrinsic, progressive, and deleterious process, inherent to all life [Strehler, 1977]. Senescence, the final outcome of the ageing process, has been defined as: "that change of the bodily faculties and sensibilities and energies which accompanies ageing, and which renders the individual progressively more likely to die from accidental causes of random incidence. Strictly speaking, the word 'accidental' is redundant, for all deaths are in some degree accidental. No death is wholly 'natural'; no one dies merely of the burden of the years" [Medawar, 1957]. Humans experience ageing as wrinkling of the skin with localized pigment plaques; graying and thinning of hair; decrease in muscular strength and agility; shrinkage and sclerosis of tendons; flattening of intervertebral discs; loss of neurons and memory; decrease of sensory capabilities, especially of sight, hearing and heat sensing; a decreased control of blood pressure, leading to essential hypertension and postural hypotension; lowered total and vital capacity of the lungs, and reduced filtering by the kidneys [Martin, 1985a]. Thus, ageing affects all tissues and organs albeit at different rates in each individual. During the past decades, numerous theories and hypotheses have been put forward to provide a general explanation for the ageing phenomenon. These theories can be broadly divided into 2 types based upon their starting point as either deterministic or stochastic theories. Deterministic theories of ageing as-

\section{KARGER}

๑๑ 2017 S. Karger AG, Basel

E-Mail karger@karger.com

www.karger.com/msy sume some sort of a program being unleashed at a certain moment during adult life, which then engenders the sequence of events leading to senescence. In contrast, stochastic theories of ageing surmise a randomly arising event which should elicit ageing.

Searching for a distinct, universal, stochastic, or deterministic cause of the ageing process, such as a single gene or the decline of a key body system proved difficult. Alternatively, ageing has been considered as a complex multifactorial process involving a multiplicity of mechanisms affecting molecular, cellular, and systemic levels [Weinert and Timiras, 2003]. Thinking along these lines, testable hypotheses at one level could be developed and investigated for their ramifications at other levels. In 1881, August Weissmann proposed that all organisms would be allowed a finite number of "acts of life," such as the number of heartbeats, air inhalations, etc. [Kirkwood and Cremer, 1982]. The experimental demonstration that cultures of the human fibroblast strain WI-38 undergo a limited number of doublings, the maximal replicative lifespan, constituted a cellular corollary of Weissmann's systemic proposal [Hayflick and Moorhead, 1961]. Apart from fibroblasts, the prototype mesenchymal cell type, a limited replicative lifespan has been demonstrated in all thus far cultured human, mammalian, and avian diploid cell types and can be considered as a model for decline and loss of function during ageing in general. Studies of

Martin Poot

Department of Human Genetics, University of Würzburg

Biozentrum, Am Hubland

DE-97074 Würzburg (Germany)

E-Mail Martin_Poot@hotmail.com 
individual cell clones in fibroblast cultures demonstrated extensive epigenetic heterogeneity within a mass culture and ruled out a simple biological clock mechanism as an explanation for clonal senescence [Martin et al., 1970]. Strikingly, fibroblasts from patients with Werner syndrome showed a dramatically shorter lifespan in culture as compared to cells from age-matched healthy individuals. Werner syndrome is an autosomal recessive disorder characterized by premature ageing-like phenotypes such as skin atrophy, graying and loss of hair, telangiectasia, muscular atrophy and bilateral ocular cataracts, which become evident during the third or fourth decade of life [Werner, 1904]. Significantly, Werner syndrome patients do not show any kind of mental retardation or other neuronal defects or decline, which sets this disorder apart from ageing as experienced within the general population. This led Martin [1985b] to consider Werner syndrome as a segmental progeroid syndrome, rather than as a form of accelerated ageing.

From a deterministic point of view, general ageing can be considered as a condition with apparent multifactorial autosomal dominant inheritance [Sacher, 1978; Schneider, 1987]. In this view, the single recessive mutation causing Werner syndrome may contribute a few aspects of senescence, but does not represent the full complement of general ageing. Second, the limited proliferative capacity of Werner syndrome fibroblasts can be reversed by fusion with "young" cells from healthy individuals, while senescent cell cultures from healthy individuals are refractory to "rejuvenation" in cell fusion experiments [Martin et al., 1974; Norwood et al., 1974; Salk et al., 1981c; Pendergrass et al., 1985]. Third, ageing of fibroblasts in culture entails a decrease in the number of cells capable of DNA replication and a lengthening of the G1 compartment of the cell cycle [Cristofalo and Scharf, 1973; Rabinovitch, 1983]. During ageing in culture, Werner syndrome cells additionally show a prolongation of the $S$ phase of the cell cycle and a decrease in average replicon size [Takeuchi et al., 1982; Hanaoka et al., 1983]. Cultures of lymphoblastoid cells form Werner syndrome patients showed a significantly elevated fraction of cells irreversibly arrested in the $\mathrm{S}$ phase and a 2.4 -h prolongation in the minimal duration of the $\mathrm{S}$ phase [Poot at al., 1992]. The latter was due to a strikingly prolonged second half of the S phase [Poot and Rabinovitch, unpublished]. Fourth, along with a protracted growth rate, cultured cells from Werner syndrome patients show a typical and diagnostic variegated chromosomal translocation mosaicism [Salk et al., 1981a, b]. These translocations are stable within a clone, but on the level of a mass culture, the karyotype is seemingly instable, due to extinction of one clone with an aberrant karyotype followed by appearance of a novel clone with a distinct karyotype. Finally, Werner syndrome cells show spontaneous deletion formation [Fukuchi et al., 1989; Oshima et al., 2002].

In view of the recessive nature of Werner syndrome, a possible defect of an enzyme involved in the cellular defence against oxygen free radicals has been investigated. In lymphocytes from patients with Werner syndrome, the activities of CuZn superoxide dismutase, Mn superoxide dismutase, catalase, and glutathione peroxidase were within the normal range [Marklund et al., 1981]. In-depth investigation of the glutathione system in cells from healthy individuals and patients with Werner syndrome revealed no deficiencies [Poot, 1991; Poot et al., 1984, 1986, 1987; Mbemba et al., 1985; Raes et al., 1987]. The gene for Werner syndrome proved to encode a $3^{\prime} \rightarrow 5^{\prime}$ helicase and a $3^{\prime} \rightarrow 5^{\prime}$ exonuclease in a single polypeptide [Yu et al., 1996, 1997; Huang et al., 1998]. Conceivably, loss of these 2 enzyme activities concomitantly may entail hypersensitivity to DNA replication-blocking lesions, possibly resulting in prolongation of the $S$ phase of the cell cycle, variegated translocation mosaicism, deletion formation, and to mesenchymal tissue atrophy as well as other features of Werner syndrome [Poot et al., 1992, 1999, 2001, 2002; Ogburn et al., 1997]. Surprisingly, complete loss of WRN helicase activity due to homozygous inactivating point mutations does not cause clinical Werner syndrome [Kamath-Loeb et al., 2017]. Nevertheless, the WRN-encoded protein may serve as a "molecular switch" between DNA damage response pathways and thus be involved in preventing complex chromosome rearrangements and chromothripsis [Sturzenegger et al., 2014; Su et al., 2014; Poot and Haaf, 2015; Poot, in press].

Recent studies indicated alterations in DNA methylation patterns in blood cells as a possible epigenetic marker of accelerated ageing in Werner syndrome [Guastafierro et al., 2017; Maierhofer et al., 2017]. These studies are based on the assumption that the physiological age of tissues can be assessed by combining the DNA methylation levels of multiple dinucleotide markers (CpGs) [Bocklandt et al., 2011; Garagnani et al., 2012; Hannum et al., 2013; Horvath, 2013; Lin et al., 2016]. By taking the weighted average across $353 \mathrm{CpG}$ sites of isolated human cells (e.g., CD4+ T cells or neurons) as a metric, known as the "epigenetic clock," the "epigenetic age" of tissues and organs, such as blood, brain, breast, kidney, liver, and lung can be determined [Horvath, 2013]. Comparison of whole blood CpG methylation data from 18 Werner syndrome patients and 18 age-matched controls showed
2
Mol Syndromol 2018;9:1-4 DOI: $10.1159 / 000484424$
Poot 
an increased epigenetic age independent of age-related changes in the cell composition of peripheral blood samples [Maierhofer et al., 2017]. A multivariate regression analysis revealed that Werner syndrome is associated with an increase in CpG methylation age of on average 6.4 years, after adjusting for chronological age, gender, and blood cell counts, such as a reduction in naïve CD8+ T cells. Thus, this study demonstrated that Werner syndrome is associated with an increased epigenetic age of blood cells, which is independent of changes in blood cell composition. An increased epigenetic age of Werner syndrome cells may reflect alterations of heterochromatin structure, which have recently been proposed as a driver of human ageing [Zhang et al., 2015].

By analyzing genome-wide DNA methylation profiles of the whole blood from 3 patients with Werner syndrome and 3 age- and sex-matched healthy individuals, hypermethylated sites were enriched for genes involved in glycosphingolipid biosynthesis, FoxO signaling, and insulin signaling pathways, while hypomethylated sites were enriched in PI3K-Akt signaling and focal adhesion pathways [Guastafierro et al., 2017]. Out of 47 differentially methylated genes, 22 , belonging to the enriched biochemical pathways, were differentially expressed in Wer- ner syndrome fibroblasts. Interestingly, the differentially methylated sites identified CERS1 and CERS3, members of the ceramide synthase family, and the ITGA9 and $A D A M 12$ genes, which show altered methylation in systemic sclerosis, as well as the PRDM8 gene, which is affected in dyskeratosis congenita and Down syndrome. Although systemic sclerosis and dyskeratosis congenita are distinct from the skin lesions in patients with Werner syndrome, the altered methylation patterns of the ITGA9 and $A D A M 12$ genes are intriguing and suggest a link between systemic sclerosis and Werner syndrome. Both the studies of Maierhofer et al. [2017] and Guastafierro et al. [2017] indicate a novel approach to the pathology of Werner syndrome and general ageing. Further research is needed to elucidate as to how precisely epigenetic changes and possibly altered gene expression patterns in somatic cells may contribute to stochastic age-related pathology in humans in general. Thinking along these lines may eventually help us to overcome the conceptual dichotomy between deterministic (e.g., mutational) and stochastic (e.g., epigenetic and chromosome rearrangement related) hypotheses for general ageing [Poot, 1991]. Martin Poot

\section{References}

Bocklandt S, Lin W, Sehl ME, Sánchez FJ, Sinsheimer JS, et al: Epigenetic predictor of age. PLoS One 6:e14821 (2011).

Cristofalo VJ, Sharf BB: Cellular senescence and DNA synthesis. Thymidine incorporation as a measure of population age in human diploid cells. Exp Cell Res 76:419-427 (1973).

Fukuchi K, Martin GM, Monnat RJ Jr: Mutator phenotype of Werner syndrome is characterized by extensive deletions. Proc Natl Acad Sci USA 86:5893-5897 (1989).

Garagnani P, Bacalini MG, Pirazzini C, Gori D, Giuliani C, et al: Methylation of ELOVL2 gene as a new epigenetic marker of age. Ageing Cell 11:1132-1134 (2012).

Guastafierro T, Bacalini MG, Marcoccia A, Gentilini D, Pisoni S, et al: Genome-wide DNA methylation analysis in blood cells from patients with Werner syndrome. Clin Epigenetics 9:92 (2017).

Hanaoka F, Takeuchi F, Matsumura T, Goto M, Miymoto T, Yamad M: Decrease in average size of replicons in a Werner syndrome cell line by Simian virus 40 infection. Exp Cell Res 144:463-467 (1983).

Hannum G, Guinney J, Zhao L, Zhang L, Hughes $\mathrm{G}$, et al: Genome-wide methylation profiles reveal quantitative views of human ageing rates. Mol Cell 49:359-367 (2013).
Hayflick L, Moorhead PS: The serial cultivation of human diploid cell strains Exp Cell Res 25: 585-621 (1961).

Horvath S: DNA methylation age of human tissues and cell types. Genome Biol 14:R115 (2013).

Huang S, Li B, Gray MD, Oshima J, Mian IS, Campisi J: The premature ageing syndrome protein, WRN, is a $3^{\prime} \rightarrow 5^{\prime}$ exonuclease. Nat Genet 20:114-116 (1998).

Kamath-Loeb AS, Zavala-van Rankin DG, FloresMorales J, Emond MJ, Sidorova JM, et al: Homozygosity for the WRN helicase-inactivating variant, R834C, does not confer a Werner syndrome clinical phenotype. Sci Rep 7:44081 (2017).

Kirkwood TBL, Cremer T: Cytogerontology since 1881: a reappraisal of August Weissmann and a review of modern progress. Hum Genet 60: 101-121 (1982).

Lin Q, Weidner CI, Costa IG, Marioni RE, Ferreira $\mathrm{MR}$, et al: DNA methylation levels at individual age-associated CpG sites can be indicative for life expectancy. Ageing (Albany NY) 8:394-401 (2016).

Maierhofer A, Flunkert J, Oshima J, Martin GM, Haaf T, Horvath S: Accelerated epigenetic aging in Werner syndrome. Aging (Albany NY) 9:1143-1152 (2017).
Marklund S, Nordensson I, Bäck O: Normal $\mathrm{CuZn}$ superoxide dismutase, $\mathrm{Mn}$ superoxide dismutase, catalase and glutathione peroxidase in Werner's syndrome. J Gerontol 36: 405-409 (1981).

Martin GM: Overview of the pathology of ageing, in Pullman B, Ts'o POP, Schneider EL (eds): Interrelationship Among Ageing, Cancer and Differentiation, pp 23-34 (D. Reidel Publishing Company, Dordrecht, 1985a).

Martin GM: Genetics and ageing: Werner's syndrome as a segmental progeroid syndrome, in Salk D, Fujiwara Y, Martin GM (eds): Werner's Syndrome and Human Ageing (Plenum Press, New York and London 1985b).

Martin GM, Sprague CA, Epstein CJ: Replicative lifespan of cultivated human cells. Effects of donor's age, tissue and genotype. Lab Invest 23:86-92 (1970).

Martin GM, Sprague CA, Norwood TH, Pendergrass WR: Clonal selection, attenuation and differentiation in an in vitro model of hyperplasia. Am J Pathol 74:137-154 (1974).

Mbemba F, Houbion A, Raes M, Remacle J: Subcellular localization and modification with ageing of glutathione, glutathione peroxidase and glutathione reductase activities in human fibroblasts. Biochim Biophys Acta 838:211220 (1985).

Editorial

Mol Syndromol 2018;9:1-4 
Medawar PB: The Uniqueness of the Individual (Methuen and Co., London 1957).

Norwood TH, Pendergrass WR, Sprague CA, Martin GM: Dominance of the senescent phenotype in heterokaryons between replicative and post-replicative human fibroblast-like cells. Proc Natl Acad Sci USA 71:2231-2235 (1974).

Ogburn CE, Oshima J, Poot M, Chen R, Hunt KE, et al: An apoptosis-inducing genotoxin differentiates heterozygotic carriers for Werner helicase mutations from wild-type and homozygous mutants. Hum Genet 101:121-125 (1997).

Oshima J, Huang S, Pae C, Campisi J, Schiestl RH: Lack of WRN results in extensive deletion at nonhomologous joining ends. Cancer Res 62: 547-551 (2002).

Pendergrass W, Salk D, Norwood T: Cell fusion studies and biochemical analysis of DNA synthesis in Werner and non-Werner cultured cells, in Salk D, Fujiwara Y, Martin GM (eds): Werner's Syndrome and Human Ageing (Plenum Press, New York, London 1985).

Poot M: Oxidants and antioxidants in proliferative senescence. Mutat Res 256:177-189 (1991).

Poot M: Genes, proteins and biological pathways preventing chromothripsis. Methods Mol Biol (in press).

Poot M, Haaf T: Mechanisms of origin, phenotypic effects and diagnostic implications of complex chromosome rearrangements. Mol Syndromol 6:110-134 (2015).

Poot M, Verkerk A, Jongkind JF: Glutathione content of cultured human fibroblasts during in vitro ageing. Mech Ageing Dev 27:315-321 (1984).

Poot M, Verkerk A, Koster JF, Jongkind JF: De novo synthesis of glutathione in human fibroblasts during in vitro ageing and in some metabolic diseases as measured by a flow cytometric method. Biochim Biophys Acta 883: 580-584 (1986).
Poot M, Verkerk A, Koster JF, Esterbauer H, Jongkind JF: Influence of cumene hydroperoxide and 4-hydroxynonenal on the glutathione metabolism during in vitro ageing of human skin fibroblasts. Eur J Biochem 162:287291 (1987).

Poot M, Hoehn H, Rünger TM, Martin GM: Impaired S-phase transit of Werner syndrome cells expressed in lymphoblastoid cell lines. Exp Cell Res 202:267-273 (1992).

Poot M, Gollahon KA, Rabinovitch PS: Werner syndrome lymphoblastoid cells are sensitive to camptothecin-induced apoptosis in S-phase. Hum Genet 104:10-14 (1999).

Poot M, Yom JS, Whang SH, Kato JT, Gollahon KA, Rabinovitch PS: Werner syndrome cells are sensitive to DNA cross-linking drugs. FASEB J 15:1224-1226 (2001).

Poot M, Gollahon KA, Emond MJ, Silber JR, Rabinovitch PS: Werner syndrome diploid fibroblasts are sensitive to 4-nitroquinolineNoxide and 8-methoxypsoralen: implications for the disease phenotype. FASEB J 16:757758 (2002).

Rabinovitch PS: Regulation of human fibroblast growth rate by both noncycling cell fraction transition probability is shown by growth in 5-bromodeoxyuridine followed by Hoechst 33258 flow cytometry. Proc Natl Acad Sci USA 80:2951-2955 (1983).

Raes M, Michiels C, Remacle J: Comparative study of the enzymatic defense systems against oxygen-derived free radicals: the key role of glutathione peroxidase. Free Radic Biol Med 3:3-7 (1987).

Sacher GA: Evolution of longevity and survival characteristics in mammals, in Schneider EL (ed): The Genetics of Ageing, pp 151-167 (Plenum Press, New York 1978).

Salk D, Au K, Hoehn H, Martin GM: Cytogenetics of Werner's syndrome cultured skin fibroblasts: variegated translocation mosaicism. Cytogenet Cell Genet 30:92-107 (1981a).

Salk D, Au K, Hoehn H, Stenchever MR, Martin GM: Evidence of clonal attenuation, clonal succession, and clonal expansion in mass cultures of ageing Werner's syndrome skin fibroblasts. Cytogenet Cell Genet 30:108-117 (1981b).
Salk D, Bryant E, Au K, Hoehn H, Martin GM: Systematic growth studies, cocultivation, and cell hybridization studies of Werner syndrome cultured skin fibroblasts. Hum Genet 58:310-316 (1981c).

Schneider EL: Theories of ageing: a perspective, in Warner HR, Butler RN, Sprott RL, Schneider EL (eds): Modern Biological Theories of Ageing, pp 1-4 (Raven Press, New York 1987).

Strehler BL: Time, Cells and Ageing, ed 2 (Academic Press, New York 1977).

Sturzenegger A, Burdova K, Kanagaraj R, Levikova $M$, Pinto $C$, et al: DNA2 cooperates with the WRN and BLM RecQ helicases to mediate long-range DNA end resection in human cells. J Biol Chem 289:27314-27326 (2014).

Su F, Mukherjee S, Yang Y, Mori E, Bhattacharya $S$, et al: Nonenzymatic role for WRN in preserving nascent DNA strands after replication stress. Cell Rep 9:1387-1401 (2014).

Takeuchi F, Hanaoka F, Goto M, Yamada M, Miyamoto T: Prolongation of $S$ phase and whole cell cycle in Werner's syndrome fibroblasts. Exp Gerontol 17:473-480 (1982).

Weinert BT, Timiras PS: Invited review: theories of aging. J Appl Physiol 95:1706-1716 (2003).

Werner O: On cataract in conjunction with scleroderma, translated by Hoehn H. (1985), in Salk D, Fujiwara Y, Martin GM (eds): Werner's Syndrome and Human Ageing (Plenum Press, New York, London 1904).

Yu CE, Oshima J, Fu YH, Wijsman EM, Hisama F, et al: Positional cloning of the Werner's syndrome gene. Science 272:258-262 (1996).

Yu CE, Oshima J, Wijsman EM, Nakura J, Miki T, et al: Mutations in the consensus helicase domains of the Werner syndrome gene. Werner's Syndrome Collaborative Group. Am J Hum Genet 60:330-341 (1997).

Zhang W, Li J, Suzuki K, Qu J, Wang P, et al: Ageing stem cells. A Werner syndrome stem cell model unveils heterochromatin alterations as a driver of human ageing. Science 348:11601163 (2015). 